\title{
EDITORIAL
}

\section{UNA VEZ MÁS CON EL DERECHO Y LA JUSTICIA}

ONCE AgAin WITH LAW AND JUSTICE

UMA VEZ MAIS COM O DIREITO E A JUSTIÇA

DOI: 10.5294/DIKA.2014.23.1.1

A finales del siglo pasado, el profesor Robert AlEXY se preguntaba "si lo que era lícito según el Derecho positivo del sistema jurídico desaparecido tenía que seguir considerándose lícito en caso de conculcar los principios fundamentales de la justicia y del Estado de derecho" ${ }^{1}$. ALEXY se refería al Derecho positivo válidamente promulgado durante el Gobierno del Tercer Reich en Alemania. La pregunta de fondo que surgia a partir de los hechos por todos conocidos es: “¿puede ser hoy injusto lo que en aquella época era Derecho?”2; o, de otra manera: ¿existe alguna relación entre el Derecho y la Justicia?, ¿tiene alguna validez el Derecho injusto?

Estas cuestiones que inquietaron a los juristas europeos - especialmente alemanes - de la segunda mitad del siglo XX (el profesor Alexy es solo uno de ellos) no solo tienen un interés teórico, sino que constituyen, fundamentalmente, una cuestión práctica, es decir, nos plantean ante todo un problema moral. Esto no quiere decir que en esta cuestión no estén involucrados elementos propiamente teóricos, incluso metafísicos en sentido estricto, pues nos pone de cara ante la tesis de la esencia misma del Derecho en cuanto ente, en cuanto realidad; pero lo que ahora pretendo decir es que una cuestión como esta nos pone de frente ante el problema del bien y del mal, en el sentido más radical. En efecto, un jurista que se exima del problema porque simplemente cree que la justicia es una "idea subjetiva", un

1 Robert AlExy, "Una defensa de la fórmula de Radbruch", en Anuario da Facultade de Dereito da Universidade da Coruña, 5 (2001), p. 75.

2 Ibid. 
"ideal" hacia el cual el derecho vigente debe aspirar y, por tanto, una cuestión que no compete al jurista - porque todo problema jurídico es en el fondo un problema de legalidad y no de justicia-, sino a quien se dedica a la moral o a la política, no ha comprendido aún cuál es el verdadero quehacer del jurista.

No es mi pretensión cavilar aquí sobre cuál debe ser el ethos del jurista, sino aportar algunos elementos a la discusión, a veces olvidada - consciente y deliberadamente olvidada-, sobre la pregunta que propuso el profesor Alexy en su artículo del año 2001. Y lo primero que es necesario poner de relieve es la naturaleza práctica de la cuestión: no es un problema solo de filosofia del derecho, de filosofía moral o de filosofia política, no, es un problema de juristas, es un problema del Derecho.

Y es que esta es una cuestión que aparece ante el Derecho a cada paso, en cada época; al profesor Alexy y a los juristas alemanes de la segunda mitad del siglo $\mathrm{XX}$ se les presentó con ocasión de las leyes injustas del régimen seudojurídico del nacionalsocialismo, y hoy en día esta cuestión sigue saliéndole al paso al Derecho, exigiendo una respuesta a los juristas. AleXY y el Tribunal Constitucional Federal alemán de la época respondieron a la cuestión acudiendo a la denominada y ya célebre "fórmula de Radbruch": "la injusticia extrema no es Derecho"3.

Para el profesor de Heidelberg, el Derecho promulgado válidamente y eficaz es verdadero Derecho - esto es, válido-, aunque sea injusto; sin embargo, las leyes positivas perderían su validez jurídica cuando la contradicción con la justicia alcanza un extremo insoportable, es decir, cuando el Derecho vigente permite o promueve conductas que de manera ostensible y hasta grotesca atenten contra los principios fundamentales de la justicia y del Estado de derecho.

Lo que para Alexy resulta original de esta "fórmula" es que no exige una coincidencia completa entre el Derecho y la moral, sino que más bien incorpora al Derecho un limite extremo: "las normas promulgadas conforme al ordenamiento y socialmente eficaces pierden su carácter jurídico o su validez jurídica cuando son extremadamente injustas" 4 .

El Tribunal Constitucional Federal alemán da un paso adelante en la comprensión de la "fórmula de Radbruch", aunque este parezca imperceptible, pues para este alto Tribunal, en las leyes y los decretos del régimen nacionalsocialista "la contradicción con la justicia ha alcanzado una medida tan insoportable que debe

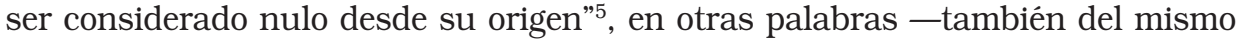
tribunal—, debe ser considerado no Derecho. Es decir, no se trata de que las normas pierdan su validez jurídica, se trata de que nunca pudieron haberla tenido; no es que los efectos de las leyes extremadamente injustas deban declararse nulos, es que nunca existieron. Los actos que se realizaron con fundamento en estas leyes, por tanto, nunca tuvieron el carácter de jurídicas, eran violencia pura y dura. Nin-

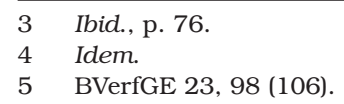


gún otro nombre merecen y, por tanto, se exige para ellas - como algo debido- no solo una fría y desnuda declaración de nulidad; merecen, además, ser castigadas.

Otra consecuencia de las leyes extremadamente injustas es que no engendran el deber de obediencia que, en condiciones normales, es obligatorio. Contrario sen$s u$, lo que engendran es el deber de desobedecerlas. En efecto, la cuestión de la obediencia al Derecho no solo depende de su legitimidad formal, es decir, de que el mismo sea creado por autoridades legítimas, sino que tiene que ver, además, con una cuestión de legitimidad material, es decir, con que el contenido de las leyes sea justo. En efecto, tal y como afirma el profesor Jaime CÁRDENAS, "si los ciudadanos respetan las normas de su país, es porque además de conocerlas y de tener noción de la importancia de su cumplimiento, saben que esas normas tienen un origen democrático y que están orientadas a salvaguardar sus derechos"6. En otras palabras, a la pregunta ¿por qué debo obedecer al Derecho? la respuesta más radical es esta: iporque es justo!

Ahora bien, esta reflexión - como decía- nos sale al paso en todas las épocas y lugares: ¿es la nuestra una excepción?, ¿existen en nuestros ordenamientos jurídicos normas insoportablemente injustas que obliguen a su desobediencia?, ¿es esta una cuestión que solo vale para el holocausto judío? En todas las épocas en las cuales se han dado leyes positivas extremadamente injustas también se encuentra quien las defienda. En la Alemania nacionalsocialista había quien lo hacía y quien sostenía que esas leyes (¡nuevas leyes y más progresistas!) significaban un avance social, un acercarse a una sociedad más feliz y próspera. Siempre las leyes injustas encuentran alguna razón en su favor, pero, como dije, esta no es una cuestión meramente teórica - de razones-, sino ante todo un problema práctico, un problema moral. ¡Claro que hoy convivimos con leyes (extremadamente) injustas!

En efecto, todas aquellas normas que atentan contra bienes como la vida de los más débiles, que en la concepción moderna autonomista del Derecho son aquellas personas que, por alguna circunstancia contingente y externa, no tienen la capacidad de ejercer su libertad, tal como los no nacidos, los enfermos terminales o las personas en situación de discapacidad, o aquellas normas que atentan contra la constitución ontológica de la familia, institución básica de la sociedad, son todas extremadamente injustas, pues atentan contra bienes básicos de la persona y de la sociedad. Por esta razón, todas ellas son normas que, por su extrema injusticia, no tienen carácter jurídico, son violencia, $\mathrm{y}$, como tales, deben ser rechazadas por quienes conformamos la sociedad política y no exigen la obediencia que reclama el Derecho válidamente constituido y justo.

José Julián Suárez-Rodríguez Editor josesuro@unisabana.edu.co

6 Jaime CÁRdenas García, Introducción al estudio del Derecho, México D. F., Nostra ediciones-UNAM, p. 313. 